\title{
Shrinking Budgets: Drivers of Europeanisation in Defence?
}

\author{
Bastian Giegerich*
}

\begin{abstract}
For defence ministries an era of austerity has begun. Observers and policy-makers suggest that the rational response to having to deal with reduced levels of defence expenditure would be to increase European cooperation. On the other hand, there is concern that financial pressure might lead governments to reduce their commitments to multinational initiatives as they retrench to the national level. Ultimately, policy choices will result from a complex interplay of budgetary constraints, political concerns, the demands of military operations as well as alliance obligations, and industrial considerations. A likely development is that governments chose to pursue interest-based, needs-based and flexible cooperation rather than full-fledged integration or re-nationalisation.
\end{abstract}

Keywords: CSDP; defence spending; defence reform; Europeanisation

GSVP; Verteidigungsausgaben; Verteidigungsreform; Europäisierung

\section{Defence in times of austerity}

A cross the EU, member state governments have been struggling with the effects of the economic crisis of 2008/09 and its implications, including ballooning public deficits in need of control. As a result, for defence ministries and armed forces an era of austerity has begun and is likely to last for the coming years. For many observers and policy-makers it seems clear that the rational response to having to deal with reduced levels of defence expenditure would be to increase European cooperation, ushering in an important change in the Europeanisation of defence. ${ }^{1}$ On the other hand, there is concern that financial pressure might lead governments to reduce their commitments to multinational capabilities-development initiatives, defence reform goals, and crisis management operations as they retrench to the national level. NATO's secretary general Anders Fogh Rasmussen implored countries not to abandon the shared agenda of creating "more flexible, mobile and modern armed forces."

The defence budget crunch is perceived to be the headline grabbing, forcing event with the potential to drive armed forces towards either Europeanisation or re-nationalisation. Economic factors will indeed be one of the central determinants shaping defence policy and the development of armed forces for the medium-term future. However, to understand recent trends and analyse likely future developments, a focus on money will not be enough and needs to be complemented by an examination of political concerns, the demands of military operations as well as alliance obligations, and industrial considerations. It is out of the complex interplay of these dimensions that policy choices will arise. This article will scrutinise them in turn to explore the Europeanisation vs. re-nationalisation hypothesis.

* Bastian Giegerich is a Senior Researcher at the Bundeswehr Institute of Social Sciences (SOWI). He writes here in a personal capacity.

1 For example: Dick Zandee (2010): How governments should compensate for defence spending cuts, in: Europe's World No. 14, pp. 30-33.

2 Anders Fogh Rasmussen (2010): Security policy in an era of budgetary constraint, Speech by NATO Secretary General Anders Fogh Rasmussen at the annual conference of the Security and Defence Agenda in Brussels, 21 June, http://www.nato.int/cps/en/natolive/opinions_64563.htm.
It should be pointed out that for this particular field of enquiry the term re-nationalisation is somewhat problematic. The use of armed forces continues to be authorised and paid for on the national level. Equipment decisions and defence industrial bases remain overwhelmingly national, as does defence spending on research and development. Multinational defence planning assumptions, advanced as they may be in the EU or NATO, have mostly failed to penetrate national processes and often governments only feed into multinational processes those capabilities they planned to procure or maintain for national reasons anyway; the limited success of the Defence Capabilities Initiative and the Prague Capabilities Commitments in NATO or the headline goals in the EU attest to this. ${ }^{3}$ In short, defence policy, and in particular the armed forces, have remained by and large national to begin with, despite the emergence of the EU's Common Security and Defence Policy (CSDP).

\section{The budget crunch}

The financial reality for the coming years is simple: there will be less money for defence and the armed forces, a trend that already started in 2009. In light of overall government priorities, defence spending has become discretionary and, correspondingly, many defence ministers have already been asked to work with less money. ${ }^{4}$ In this context, a greater degree of Europeanisation holds the promise of 'spending better'; of using scarce financial resources more efficiently. Europeanisation would imply spending more money together through methods such as the pooling and sharing of capabilities, the use of (ideally complementary) role and task sharing for the armed forces of EU member states, and joint acquisition, including collaborative research and development

3 Bastian Giegerich and Alexander Nicoll (2008): European Military Capabilities: Building Armed Forces for Modern Operations (IISS: London), pp. 2428.

4 Stephen Fidler, Alistair MacDonald, Patrick McGroarthy (2010): In Europe, U.S. Allies target Defense Budgets, Wall Street Journal, 25 June. 
(R\&D). ${ }^{5}$ Employing such methods, which in themselves are not new and have been used already in the past, would generate a better use of resources because of the economies of scale resulting from, for example, bigger order books, which bring down unit costs for acquisitions, and from efficiency gains enabled by reducing support functions and unnecessary duplications among European militaries.

The counter-argument would be that higher degrees of collaboration would also demand higher degrees of coordination, which potentially increase costs. In a joint acquisition project, for example, the partners might not be able to harmonise their requirements enough and those different preferences might lead to the introduction of technical risk to a project, all of which is likely to cause delays and extra costs. Thus, if done wrong, the potential savings generated by cooperation could be directly outweighed by financial demands stemming from that very cooperation. ${ }^{6}$ It might therefore be tempting to avoid such entanglements in the first place and opt for national programmes.

Looking at the recent past, it is clear, however, that EU member state governments invest very little of their defence expenditure together. According to data provided by the European Defence Agency (EDA), some 76\% of all defence investment (equipment procurement plus R\&D) by EU member states in 2008 was spent on national programmes that do not involve international collaboration. For research and technology, an area that will help determine future capabilities, this figure rises to $82 \%{ }^{7}$ There is thus clear evidence that governments in Europe continue to spend money on their national supplier bases, generating duplications and, up to now, where quite willing to pay for those market inefficiencies. ${ }^{8}$

If one now takes a closer look at defence spending cuts that were announced over the course of the last 18 months or so, it emerges that governments do not coordinate the measures they adopt. Instead of a European perspective, which would at the bare minimum ensure that governments are aware of the precise nature of cuts adopted by another government and thus are able to make decisions based on this information, austerity measures are imposed from a purely national point of view and sometimes with little forethought inflicting blanket cuts on nearly everything.

Even large EU member states with considerable outlays for defence will face tough choices. For example, it is not clear whether Italy will be able to renew funding for major acquisition

5 EU member states were explicitly encouraged to consider these methods by the 2008 French EU presidency. See: European Union (2008): Declaration on Strengthening Capabilities, Brussels, 11 December, http://www.consilium. europa.eu/ueDocs/cms_Data/docs/pressData/en/esdp/104676.pdf.

6 For more details and examples see: Bastian Giegerich (2010): Budget Crunch: Implications for European Defence, in: Survival Vol. 52(4): 87-98.

7 European Defence Agency (2010): Defence Data 2008, 29 January 2010, pp. 15-17, http://www.eda.europa.eu/documents.aspx.

8 Studies that have looked at major programmes awarded in the period of 2006 to 2008 suggest that there is a shift towards competitive and cooperative procurement. While more recent data is not yet available, it will be interesting to see whether this trend continues or at least solidifies in light of the new financial realities. For the analysis of the earlier data see: Jeffrey P. Bialos, Christine E. Fisher and Stuart L. Koehl (2009): Fortresses \& Icebergs: The Evolution of the Transatlantic Defense Market and the Implications for U.S. National Security Policy (Center for Transatlantic Relations: Washington, DC). programmes (frigates and armoured vehicles) in $2011 .{ }^{9}$ Germany's plans to cut public spending will force escalating defence cuts, and defence minister Karl Theodor zu Guttenberg indicated that such reductions could only be managed if they were accompanied by structural reform of the armed forces. He suggested that the German defence budget was running a EUR 14bn structural deficit between 2010 and $2014 .{ }^{10}$ In the United Kingdom, a government spending review suggests that defence spending, like spending in other ministries, could be cut by up to $25 \%$ over four years. Given that the past years already revealed a structural underfunding of the British acquisition programme to the tune of GBP 15bn it is hard to see how the upcoming strategic defence and security review (SDSR), due to be published in October 2010, can avoid reducing capability.

On average, just over $50 \%$ of the defence expenditure of EU member states is spent on personnel. ${ }^{11}$ Past efforts have shown how difficult it is to control personnel costs unless manpower is cut drastically. Many governments might chose a road of less resistance and focus cuts on procurement programmes and on research and development with potentially alarming consequences for future capabilities. Likewise, countries might be forced to reduce their contributions to international crisis management operations because of the financial constraints. Poland has already taken the latter step pointing to budgetary constraints. $^{12}$

Lack of money could have a positive effect if it acts as a catalyst for transformation forcing armed forces to eliminate legacy capabilities that have lost relevance in contemporary circumstances. It also creates pressure to expand cooperative methods such as pooling and sharing, role specialisation and joint acquisition. From a purely economical perspective, the financial pressure should lead to greater levels of cooperation. So far, however, governments across Europe are not coordinating their responses to the budget crunch and the resulting adjustments in the defence arena. If there is a Europeanising effect of the budget crisis it is likely to unfold over the coming years as governments step back from the immediate and shortterm task of controlling deficits and adopt a more strategic and long-term perspective.

\section{Political constraints}

A driver for greater Europeanisation is the assessment that individual EU member states can only hope to develop effective responses to contemporary security challenges by working together. Collaboration would make it easier to make a European voice heard on the global stage. As the EU's security strategy argues, while "no single country is able to tackle today's complex problems on its own", the EU "is inevitably a

9 Paolo Valpolini (2009): Italian armed forces braced for budget cuts, in: Jane's Defence Weekly, 27 November.

10 Karl-Theodor zu Guttenberg (2010): Security Today and Tomorrow, 2010 Alastair Buchan Memorial Lecture, International Institute for Strategic Studies, London, 28 June, http://www.iiss.org/conferences/alastair-buchan/ alastair-buchan-lecture-2010/.

11 European Defence Agency (2010), p. 8

12 Grzegorz Holdanowicz (2009): Poland mulls 2010 defence budget, in: Jane's Defence Weekly, 17 September. 
global player."13 Likewise, a European framework should make it easier in principle for smaller EU member states to influence international policy because the EU provides them with an opportunity to voice their positions. On the other hand, national governments will rightly be concerned about reduced levels of national autonomy inevitably resulting from further collaboration in defence policy. Thus, as far as the political dimension is concerned, Europeanisation creates a tension between influence and autonomy and governments will have to consider where they want to strike the balance.

Institutions channel conflicts between autonomy and influence and make the balancing process between those variables more predictable. While perhaps more acute for small states, all governments will have to worry about the "alliance security dilemma." 14 Its basic assumption is that countries which are collaborating closely will fear abandonment by their partners in case of an external conflict situation, in particular if they are seen as being overly concerned with their own national autonomy. On the other hand, they will fear entrapment, the fear of being dragged into a conflict by allies, because the intensity of cooperation with partners could make it impossible to withhold that cooperation. Balancing the costs and benefits of cooperation is made particularly difficult by the fact that abandonment and entrapment seem to be inversely related, meaning that attempts to limit the danger of abandonment (for example, through increasing cooperative measures) will increase the danger of entrapment and vice versa.

In the context of the EU, with its repeated and near constant processes of negotiation spanning most areas of policy, sovereignty still exists in a formal and legal sense, but in reality national autonomy is being redefined and influenced through interaction in the EU framework. Mutual dependencies among member states are so strong and manifold that autonomy can in practice only be implemented in conjunction with other member states. Cooperation could, therefore, ironically be a means to serve the end of maintaining a degree of national autonomy. ${ }^{15}$ Formal national autonomy is relatively pointless if it cannot generate the outcomes desired by governments. Addressing today's security challenges from a purely national point of view would be a case in point.

On the other hand, a shift towards a narrower, more directly national perspective could be driven by divisions among member states regarding threat perceptions. At a time when international security challenges have become more complex and have diversified, it would be logical to expect threat perceptions to diversify as well. There is, on the surface, great coherence among threat assessments in major strategy documents on the national and multinational level. International terrorism, proliferation of weapons of mass destruction, fragile states, intra-state and regional conflicts,

13 European Union (2003): A Secure Europe in a Better World, 12 December, Brussels, p. 2, http://www.consilium.europa.eu/uedocs/cmsUpload/78367. pdf.

14 Glenn H. Snyder (1997): Alliance Politics (Ithaca: Cornell University Press), in particular p. 180; Anders Wivel (2005): The Security Challenge of Small State EU Member States: Interests, Identity and the Development of the EU as a Security Actor, in: Journal of Common Market Studies Vol. 43(2), S. 393-412.

15 Johann Frank and Sammi Sandawi (2005): Möglichkeiten und Grenzen der EU-Streitkräfteintegration: Chancen und Perspektiven für kleinere Staaten am Beispiel Österreichs (Vienna: Büro für Sicherheitspolitik), p. 12. organised crime and residual territorial threats, as well as concerns such as cyber and energy security are routinely listed. Drivers and potential multipliers of risk such as climate change, demographic developments, resource challenges, extremism, and pandemics are also almost universally seen as key aspects. What is revealing, however, is that there are very few attempts by governments to establish clear priorities or even a hierarchy of risks and threats. ${ }^{16}$ The laundry list character of many threat assessments suggests that there is no unifying narrative among EU member states as to how to respond to the diverse set of challenges.

In addition, governments do not seem to agree on the purpose of concrete measures that would bring about more Europeanisation. Consider the instrument of permanent structured cooperation on defence (PSCD), which, under the Treaty of Lisbon, is intended to facilitate more effective development of capabilities for crisis management operations. On paper, PSCD allows member states with strong military capabilities to set up a leadership group to cooperate more closely - in fact that was the idea behind PSCD when the concept was first developed. The underlying rationale for such a procedure should be to generate relevant and useable capabilities for EU operations with greater financial efficiency. However, member states are far from agreement on how this process should be organised or, in fact, whether it is feasible at all. ${ }^{17}$ Several governments saw PCSD as a means to foster closer cooperation on defence among member states and argued that it should be as inclusive as possible, ideally involving all member states. Others argued that PSCD should be open only to members who were willing and able to commit to generating better capabilities, and should therefore be self-selective. Thus, two camps emerged with one arguing that the primary goal should be political inclusiveness even if that carries a cost in terms of effectiveness with the other group arguing the opposite. In the absence of consensus, several governments began to argue that PSCD was threatening to be too unwieldy and should not be activated at all. It is a testament to the lack of resolve of EU leaders that an instrument heralded as a potential "change agent" for European capabilities stood a good chance of failing before even starting. ${ }^{18}$

\section{The defence industrial base}

For some time now major defence industrial actors in Europe have, independent of government intervention, undertaken steps towards consolidation in order to capture new markets and new technologies to secure the economic viability of

16 For example, whereas the French security and defence white paper from 2008 does offer a partial hierarchy based on the likely probability and likely impact of threats, neither the German equivalent from 2006 nor the British national security strategy from 2008, updated 2009, offers further guidance. See: Alexandra Jonas (2010): Bis an die Grenzen der Vorstellungskraft? Sicherheitspolitische Bedrohungsanalysen, in: Alexandra Jonas and Nicolai von Ondarza (Eds.): Chancen und Hindernisse für die europäische Streitkräfteintegration (Wiesbaden: VS-Verlag), pp. 31-41.

17 Brooks Tigner (2010): Goal of 'inner group' EU co-operation 'no closer', in: Jane's Defence Weekly, 10 March, p. 22.

18 Julian Lindley-French (2005): A Long-Term Perspective on Military Integration, in: Sven Biscop (Ed.): E Pluribus Unum? Military Integration in the European Union (Brussels: Egmont Institute), pp. 39-41 (here p. 40). 
their businesses in light of shrinking home markets. Those steps included mergers and acquisitions, joint ventures, and consortia to respond to specific procurement programmes. ${ }^{19}$ Will the economic downturn and the defence spending crunch now lead to industrial consolidation in the defence sector with a view to an emerging European defence industrial base?

On the one hand, if governments opt for more common spending and procurement, consolidation pressures for industry would increase, possibly leading to fewer industrial duplication and more synergies, both of which would save money. On the other hand, the crisis might be an incentive to play up protectionist tendencies in order to protect jobs and skills and provide a strong justification for the expenditure of taxpayers' money on national defence contracts. Furthermore, a government might insist on certain types of equipment and supplies being produced and procured at home as to ensure independence from foreign suppliers who might cut off deliveries in times of conflict. Clearly, there are more than purely commercial considerations at play in the defence market.

Interestingly, current developments take place against the context of EU institutions emerging as regulators in the defence market in Europe, developing strategy and legislation on the EU level. In 2005, the EDA introduced a voluntary code of conduct which commits participating member states to opening much of their procurement to European competition. This move was followed in 2007 by calls for a European Defence Technological and Industrial Base (DTIB) and the introduction of a code of conduct on defence offsets with the aim of reducing their use. On the side of the European Commission, a directive on defence procurement was adopted in early 2009 which is to come into effect in 2012. It aims to harmonise the application of provisions in EU treaties that allow member states to exempt much of their defence procurement from EU common market legislation. Like the EDA code of conduct, the aim of the directive is to increase the amount of defence procurement that is open to European and other international competition. If implemented properly, these measures should result in fewer market distortions and more competition which in turn may lead to industry consolidation in Europe.

As French president Nicolas Sarkozy suggested, the existence of "five ground-to-air missile programmes, three combat aircraft programmes and around twenty tank programmes" among EU member states illustrate the shortcomings. ${ }^{20}$ In addition, programmes that are collaborative on paper have often produced national versions of the same equipment that ended up being so different from each other that potential benefits of collaboration did not materialise. Add to this the practice of insisting on work-share arrangements to allocate workloads to different national industries based on the size of the order of particular national governments. These juste retour practices protect national industries but again prevent consolidation. Evidence suggests, thus, that governments up until recently were still willing to protect their national supplier base by

19 See Giegerich and Nicoll (2008), pp. 99-111.

20 Nicolas Sarkozy (2007): Speech at Le Bourget, 23 June, http://www.ambafrance-uk.org/president-sarkozy-s-speech-at-Le.html. essentially financing industrial overcapacity through expensive, and in some cases duplicative, procurement programmes.

Up to now fragmented demand has helped sustain fragmented supply. EU defence ministers have recognised that such an approach might no longer be viable. Meeting in format of the EDA's steering board, they declared in 2007, “.... a fully adequate DTIB is no longer sustainable on a strictly national basis - and we must therefore press on with developing a truly European DTIB, as something more than a sum of its national parts." ${ }^{21}$ Clearly, the highly politicised nature of the defence industry presents an obstacle to this goal because European consolidation would imply job losses and reduced technological capacity for some countries while others might thrive.

From a business point of view, however, the defence industry would find it much easier to structure itself more efficiently if governments were to make progress on harmonising their defence requirements and could provide clear direction on what kind of investment can be expected. Speaking in the UK context, Ian King, chief executive of BAE Systems, said government had to answer the question "what industrial sovereign capacity will we retain in the UK? We want a list of programmes that are safe and we will respond accordingly." 22 In other words, industry leaders realise that budget cuts will produce winners and losers among them and they are looking to understand government priorities for the future so that they can adjust their business models accordingly.

It is possible that Europeanisation takes the form of industrial specialisation, a move that would require a high level of trust among governments so that security of supply concerns can be mitigated. Even if this were to occur, the political constraints are considerable. For many defence companies, however, the domestic market in their home countries is too small to sustain them. They depend on competitive and cooperative international procurement for profits and have long taken on an international outlook. Hence, most contractors have very little appetite for protectionist measures.

Only a handful of EU member states have defence industries of a significant size. It seems that these member states will have to decide which part of the defence industrial sector they perceive to be of crucial importance for national security. So-called sovereign capabilities, areas that a government is unwilling to see wither away or move abroad because they are uncomfortable relying on others for the capability in question, are likely to be high technology and knowledge-intensive areas. For European governments it would make sense to coordinate any discussions about sovereign capabilities among themselves. If every EU member state with a sizeable defence industry defines exactly the same areas as sovereign capabilities, it will be difficult to restructure efficiently. In any case, whether the driver is defence-industrial or political, an intergovernmental exercise, among EU member states, of defining respective sovereign capabilities would be an important step forward. Knowing what governments see as sovereign capabilities

21 European Defence Agency (2007): A Strategy for the Defence Technological and Industrial Base, 14 May, http://www.eda.europa.eu/genericitem. aspx? area $=30 \& i d=211$.

22 Quoted in: David Robertson (2010): Defence on the cheap will destroy industry, warns BAE chief, in: The Times, 14 July, p. 31. 
means knowing which areas will remain beyond the reach of cooperation. Furthermore, areas not defined as sovereign capabilities could then be systematically assessed with a view to identifying which countries might want to collaborate in which particular form and on what specific capability.

\section{The operational context}

At a time when the deployment of EU member states' armed forces beyond their own territory happens almost exclusively in multinational frameworks, be it through the EU, NATO, the $\mathrm{UN}$, or in form of a coalition of the willing, increasing levels of Europeanisation could be seen as particularly attractive because they might lead to greater standardisation and harmonisation among armed forces, which in turn should translate into greater interoperability. The militaries of member states would thus be better prepared to operate together. An underlying assumption of defence reform efforts in Europe for the past decade has been that deployment in international operations is a core mission for the armed forces and that the capabilities needed to do so are not dissimilar from those needed for contemporary homeland defence tasks. However, while almost all EU member states have made considerable commitments to overseas crisis management missions dealing with a diverse sets of circumstances, the success of those operations has often been limited and in some cases, such as Afghanistan, outright elusive. There is thus the possibility that the political and military appetite for intervention abroad will be lower in the future and governments might refocus on tasks closer to home, revisiting capability goals in the process.

In order to avoid costly and long-term deployments with unclear outcomes, governments might also insist on more clearly defined criteria to launch operations and demand a direct link to their national security in order to build domestic support for the deployment. The controversial debates about the NATO-led mission in Afghanistan and the dropping support for it in many European countries underline the difficulty. Some governments chose to focus on the threat emanating from regional instability, others emphasise terrorism or international narcotics trade, whereas yet again others stress humanitarian and reconstruction tasks. Sceptic electorates are increasingly taking the view that neither is an important enough reason to justify the expenditure of blood and treasure.

Multinational military units are often interpreted to signal increasing levels of Europeanisation because they represent a way of sharing capabilities among countries. While there is a flurry of multinational formations, bringing together military elements from two or more EU member states, those formations very rarely deploy together as formed units. The EU Military Committee (EUMC) has studied many existing multinational forces that could potentially be employable in CSDP missions. ${ }^{23}$ The details of this work are not in the public domain. However, the EU Battlegroups, which were excluded from the EUMC's study, will serve to illustrate some of the problems.

23 See: European Union (2009): Multinational forces potentially employable in an ESDP Framework - Way ahead, 23 June, Document No. 11305/09, http:// register.consilium.europa.eu/pdf/en/09/st11/st11305.en09.pdf.
Since 2007, two rapid-response battlegroups are on call at any time for EU operations, each made up of at least 1,500 troops and able to reach a strength of 3,000 if all 'enabling' capabilities are included. Most of the formations comprise units from several member states. So far, however, no battlegroup has actually been deployed in an operation. When potential missions have been discussed, alternative means of carrying them out have been agreed upon. For example, some governments suggested the deployment of an EU battlegroup to Chad and the Central African Republic in response to calls by the UN secretarygeneral for an EU operation. A mission was indeed launched in early 2008, but the battlegroups on call were not used and different European units were deployed. In another instance, in 2006, the German government resisted pressure to deploy the on-call Franco-German Battlegroup to the Democratic Republic of Congo (DRC). The battlegroup in question consisted almost entirely of German soldiers, and politicians found it hard to see a direct German national interest that would justify such a pronounced role for Germany. In the event, Germany led a multinational EU mission, EUFOR Congo, outside the battlegroup framework.

A common response to the observation that battlegroups are of questionable value if they are not being used, is that the crisis situation in question did not call for a battlegroup deployment, because the crisis demanded different capabilities: Battlegroups, so this argument, have not been used because the appropriate scenario has not yet arisen. If this argument persists, the battlegroups concept is flawed given that there is no shortage of crises: surely one would fit the spectrum of operations for which the battlegroups were designed.

The examples provided underline that even when governments have created a Europeanised capability to conduct operations, the decision to actually do so is a different matter. States that are leading (or are participating in) a battlegroup might in a given case not be willing to accept the political and military responsibility on behalf of the European Union. In other circumstances, countries might be willing to deploy their battlegroup, but the necessary consensus among all EU member states to launch the operation might not be forthcoming. In the latter case, countries that have invested money to provide the battlegroup will think twice about whether the investment is worthwhile when their slot in the battlegroup roster comes up again. It is no accident that Sweden, which allegedly was ready to deploy the so-called Nordic Battlegroup it led in 2008 to Chad, chose to initiate a discussion during its 2009 EU presidency on how the battlegroups concept could be made more flexible with a view to enabling deployment. ${ }^{24}$ Overall, the conundrum is that the contemporary operational environment calls for multinational missions - in which nearly all EU member states participate regularly - and yet national governments maintain firm control over the actual decision to deploy. Given that, for the time being, no multinational framework can replace the legitimacy and accountability of the national political system necessary to send soldiers into harm's way, this circumstance is unlikely to change.

24 See: IISS (2009): Europe's rapid-response forces: use them or lose them? in: Strategic Comments Vol. 15(7), September. 


\section{Concluding remarks}

Re-nationalisation is not an attractive option - while that does not mean it can be ruled out, the pressures emanating from a variety of directions make it at least an unlikely future. Over the last decade, the area of defence policy has become more Europeanised, even though it is surprising to see how much in defence remains national despite the existence of the EU's CSDP. Cooperation on defence through CSDP was almost entirely driven by the voluntary use of bottom-up logic. It did not take the budget crunch to reveal that such cooperation will remain limited and tends to be driven by national preferences that may or may not fit into larger multinational goals. The economic and financial pressures do, however, increase the pressure to make such cooperation more efficient, which would suggest a stronger dimension of top-down direction from the EU level.
Nonetheless, defence policy and the armed forces remain sensitive areas which governments continue to see as touching upon the very essence of their sovereignty. Because there are push and pull factors at work it seems that Europeanisation in form of integration on the EU level will remain a remote possibility. A much more likely development would be that governments chose to pursue project-based cooperation bringing together groups of EU member states for pragmatic, problem-oriented efforts. Cooperation will thus be interestbased, needs-based and flexible. EU-level institutions such as the EDA would have an important role to ensure that such variable geometry pursues broadly aligned goals so that a fragmentation of member state initiatives is prevented.

\title{
Hybrid Threats: The Shape of Wars to Come
}

\author{
Sammi Sandawi*
}

\begin{abstract}
Within the last few years, the idiom 'hybrid threats' has become a popular buzzword to describe the complex amalgam of conventional military power combined with irregular tactics, criminal structures and/or asymmetric activities to generate a strategic advantage over traditional armed forces. However, the international debate remains largely limited to new ways of insurgency and counterinsurgency, and is not close to addressing the scale and complexity of the future threat appropriately. The debate tends to focus mostly on operational areas like Lebanon or Afghanistan and too often neglects the domestic domain and the disruptive character that hybrid attacks have on highly complex Western societies. The aim of this article is to broaden the debate on hybrid threats as well as to articulate the parameters of hybrid threats facing Western states - now and in the future.
\end{abstract}

Keywords: Networked security, hybrid threats, critical infrastructure, non-state actors, new vulnerabilities, irregular warfare Vernetzte Sicherheit, hybride Bedrohungen, kritische Infrastrukturen, nichtstaatliche Akteure, neue Verwundbarkeiten, irreguläre Kriegführung

\section{Introduction}

$\mathrm{A}$ look at current risks and threats reveals an increasing number of fields of action that are relevant to security policy. This is because the last two decades saw changes on the political, social, technological, economic and military levels that have not only entailed greater freedom for individuals and societies in many countries but have, at the same time, also led to a large number of new risks and vulnerabilities. In this context, it is in particular

- the increased permeability of traditional territorial borders,

- the blurring of the roles of actors in the field of security policy (state/non-state, civil/military, national/international) and

* The author is researcher and political advisor at the Bundeswehr Transformation Centre (Strausberg/Berlin) and the German representative at the NATO-working group on 'Countering Hybrid Threats' (CHT). The views expressed in this article are those of the author and do not represent the views of the German Armed Forces.
- increased proliferation of defence articles and dual-use goods

that have over the years, promoted the insidious erosion of the state's monopoly of force and have led to an exponential increase in interdependencies between the regions of the world, different policy fields and social entities. This process coincides with the global fusion of knowledge, information and opinion in a virtual real-time/cross-media environment that is extremely vulnerable to manipulation, and society's ever-growing dependence on critical infrastructures (CI) and technologies that are essential for everyday life.

Both in terms of national and international security, these developments have led to a dramatic increase in complexity which creates a number of new vulnerabilities to be exploited by potential (state and non-state) adversaries. In addition to the penetration of direct vulnerabilities, a significantly larger number of indirect effects can be imagined which make themselves felt with delay, indirectly or only in combination 